Bangladesh J. Pl. Breed. Genet., 20(2) : 17-22, 2007

\title{
EFFECT OF PLANT GROWTH REGULATORS FOR INDUCTION OF PARTHENOCARPIC FRUIT IN KAKROL (Momordica dioica Roxb.)
}

\author{
R. N. Chowdhury, M. G. Rasul, A. K. M. A. Islam, M. A. K. Mian and J. U. Ahmed ${ }^{1}$ \\ Department of Genetics and Plant Breeding \\ Banghabandhu Sheikh Mujibur Rahman Agricultural University \\ Gazipur 1706, Bangladesh
}

\begin{abstract}
An experiment was conducted to find out the suitable plant growth regulator(s) for inducing parthenocarpic fruit in kakrol (Momordica dioicia Roxb). Four plant growth regulators, viz. NAA and 2, 4-D (Auxins), Fulmet (Cytokinine) and $\mathrm{GA}_{3}$ (Gibberellic acid) were sprayed at three stages (a day before anthesis, at anthesis, a day after anthesis). Out of four growth regulators 2, 4-D and fulmet induced parthenocarpic fruit development. Fruit set percent, final fruit weight, fruit length and fruit diameter varied significantly with different treatment combinations. 2, 4-D at $50 \mathrm{ppm}$ when applied at anthesis showed better performance in inducing parthenocarpy.
\end{abstract}

Key words: Momordica dioica, plant growth regulators, parthenocarpic fruit

\section{INTRODUCTION}

Kakrol (Momordica dioica Roxb.) belongs to the family Cucurbitaceae having chromosome no $2 x=2 n=28$. It is a dioecious plant and propagated vegetatively through tuberous roots. Kakrol is a summer vegetable grown widely in Bangladesh. It is available in the market in the lean period for vegetables (April-October). It can stand handling well in transportation and has a good shelf life. It is rich in carotene, protein, carbohydrate (Rashid, 1993) and vitamin C. It's cultivation is two times more profitable than rice, jute or any other summer vegetables (Das, 1988). Among the problems relating to its yield and fruit quality low yield, small sized fruit, low bearing, lack of flowering synchronization of male and female plants, regular cumbersome hand pollination, presence of a large number of hard seeds in the fruit are considered to be important. Presence of hard seeds in the fruits 14-16 days after anthesis deteriorates the palatability of the vegetable. As kakrol is a dioecious cross-pollinated crop, female flowers need to be hand pollinated for high rate of fruit setting. If a seedless or less seeded fruit could be developed the above two problems could be avoided and the harvesting period would be extended. Seedless or less seeded fruit could be developed through parthenocarpy. In absence of natural or genetic parthenocarpy alternate methods should be adopted to have seedless fruits. Parthenocarpy had been induced in many crops (Cucumber, tomato, bottle gourd, brinjal, cucurbits, watermelon etc.) by exogenous application of phytohormone, viz. auxins (Elassar et. al., 1974a), gibberellins and cytokinins (Choudhury and Phatak, 1958; Elassar et. al., 1974b; Yu, 1999; Hayata et. al., 2000) and

\footnotetext{
${ }^{1}$ Department of Crop Botany, Banghabandhu Sheikh Mujibur Rahman Agricultual University, Gazipur 1706, Bangladesh.
} 
also auxin transport inhibitors (Cantliffe, 1977). Growth regulators may be used to increase the fruit size of existing parthenocarpic genotypes for yield improvement. There are some reports on application of growth regulators in cucumber to induce parthenocarpy (Choudhury and Phatak, 1959), only few complete reports are available in Kakrol (Manik, 1998; Rasul, 2003). Therefore, the present investigation was designed to identify a growth regulator and suitable stage of application for inducing parthenocarpy in kakrol.

\section{METHODS AND MATERIALS}

The experiment was conducted at the experimental field under Department of Genetics and Plant Breeding, Bangabandhu Sheikh Mujibur Rahman Agricultural University (BSMRAU), Gazipur, during the kharif season (March to September, 2004) on an upland soil. The tuberous roots of a local genotype were used in this study. The experiment was carried out in a split plot design with three replications. The treatments imposed were time of application of growth regulator, one day before anthesis $\left(A_{1}\right)$, at anthesis $\left(A_{2}\right)$, one day after anthesis $\left(\mathrm{A}_{3}\right)$ and different plant growth regulators: 2, 4-D: (2, 4-dichlorophenoxy acetic acid) $\left(\mathrm{H}_{1}\right)$, Fulmet $\left(\mathrm{H}_{2}\right), \mathrm{GA}_{3}$ : Gibberellic acid $\left(\mathrm{H}_{3}\right)$, NAA: nepthalene acetic acid $\left(\mathrm{H}_{4}\right)$. Stages of spraying were arranged in the main plot, and different plant growth regulators were applied to sub plot. The 2, 4-D, Flumet, $\mathrm{GA}_{3}$, NAA were dissolved in $1 \%$ ethanol to make $50 \mathrm{ppm}$ concentration. The solution of growth regulators (at 50ppm conc) was applied with a spray to ovaries of bagged female flowers according to the rate of $0.5 \mathrm{ml}$ (equal to $25 \mu \mathrm{g}$ ) per ovary. The control ovary was sprayed only with water. Ten ovaries were selected randomly for each of three replicates at first fruiting stage and were treated with each plant growth regulator. All the treated flowers were bagged in the afternoon one day before anthesis, and rebagged after application of hormones for 3-4 days to prevent open pollination. Data on ovary length $(\mathrm{mm})$, ovary diameter $(\mathrm{mm})$ were taken at just before and 5,10 and 15 days after spraying (DAS), fruit weight after 15 days after spraying and fruit set percentage were also calculated. The data were analyzed statistically and mean separation by DMRT.

\section{RESULTS AND DISCUSSIONS}

\section{Effect of plant growth regulators on parthenocarpy}

Out of four growth regulators, 2, 4-D and NAA has auxin property and Fulmet has cytokinin property. There are many reports on the induction and improvement of fruit set by auxins in tomato, grape, cucurbit etc. (Elassar et. al., 1974; Shishido et. al., 1990; and Kim et. al., 1992). Besides auxin and its analogenous, cytokinin and its derivatives have also been used to induce parthenocarpic fruit development in many crops (Schwabe and Mills, 1981), of which watermelon (Hayata et. al., 1995), cucumber (Shishido et. al., 1990), chinese white flowered gourd (Yu, 1999), kiwi fruit (Lewis et. al., 1996;), melon (Gotou et. al., 1989), tomato (Chin et. al., 1991) etc are important. It is evident from Table 1 and Table 2 that the effects of growth regulators viz. 2,4-D, Fulmet, GA $_{3}$ and NAA on fruit set percent, fruit length, fruit diameter and fruit weight were statistically highly significant. The maximum fruit set was obtained with 2, 4-D (90.00\%) followed by Fulmet $(88.89 \%)$, which was statistically similar. The minimum fruit set was observed with the treatment $\mathrm{GA}_{3}(68.89 \%)$ which was statistically different from other growth regulators. The size of fruit (fruit length and diameter) varied considerably with different treatments. Unlike pollinated fruit, hormone treated fruit turned into yellow after 10DAS which may be due to cessation of cell division for want 
of auxin supply (Fig 1A-B).Only hormone treated ovary developed into small fruit without seeds (Fig 1C).
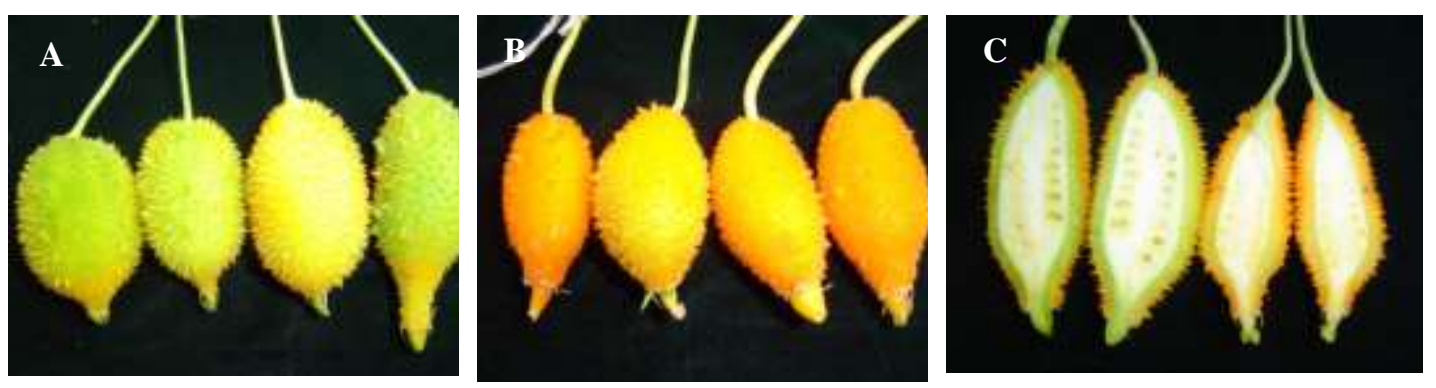

Fig. 1. Fruit development with 2, 4-D treatment which started turning (A) green (B) yellow 10 days after spraying, (C) 2, 4-D treated fruits in kakrol (no seeds)

Table 1. Mean effect of plant growth regulators $(\mathrm{H})$ and stages of application $(\mathrm{A})$ on fruit length $(\mathrm{mm})$ and fruit diameter ( $\mathbf{m m}$ ) in pathenocarpic fruit development in karol

\begin{tabular}{l|c|c|c|c|c|c|c|c}
\hline \multirow{2}{*}{ Treatment } & \multicolumn{9}{|c|}{ Fruit length (mm) } & \multicolumn{4}{c}{ Fruit diameter (mm) } \\
\cline { 2 - 10 } & at spraying & 5 DAS & 10 DAS & 15 DAS & at spraying & 5 DAS & 10 DAS & $15 \mathrm{DAS}$ \\
\hline $\mathrm{H}_{1}(2,4-\mathrm{D})$ & 14.78 & $42.53 \mathrm{a}$ & $55.85 \mathrm{a}$ & $56.88 \mathrm{a}$ & $7.146 \mathrm{a}$ & $17.96 \mathrm{a}$ & $26.51 \mathrm{a}$ & $31.58 \mathrm{a}$ \\
$\mathrm{H}_{2}$ (Fulmet) & 14.46 & $32.32 \mathrm{~b}$ & $38.06 \mathrm{~b}$ & $40.84 \mathrm{~b}$ & $6.823 \mathrm{~b}$ & $16.97 \mathrm{~b}$ & $21.41 \mathrm{~b}$ & $22.67 \mathrm{~b}$ \\
$\mathrm{H}_{3}$ (GA $\left.\mathrm{GA}_{3}\right)$ & 14.55 & $17.85 \mathrm{c}$ & $18.64 \mathrm{c}$ & $19.69 \mathrm{c}$ & $6.71 \mathrm{~b}$ & $8.128 \mathrm{c}$ & $8.564 \mathrm{c}$ & $8.89 \mathrm{c}$ \\
$\mathrm{H}_{4}$ (NAA) & 14.91 & $17.84 \mathrm{c}$ & $18.62 \mathrm{c}$ & $19.81 \mathrm{c}$ & $6.677 \mathrm{~b}$ & $7.932 \mathrm{c}$ & $8.473 \mathrm{c}$ & $8.743 \mathrm{c}$ \\
\hline F-test & $\mathrm{NS}$ & $* * *$ & $* * *$ & $* * *$ & $* * *$ & $* * *$ & $* * *$ & $* * *$ \\
\hline Mean & 14.675 & 27.635 & 32.792 & 34.305 & 6.839 & 12.747 & 16.239 & 17.970 \\
\hline $\mathrm{A}_{1}$ (Before anthesis) & $13.20 \mathrm{c}$ & $29.23 \mathrm{~b}$ & $35.64 \mathrm{a}$ & $35.83 \mathrm{a}$ & $5.99 \mathrm{~b}$ & $12.54 \mathrm{~b}$ & $16.59 \mathrm{a}$ & $17.82 \mathrm{a}$ \\
$\mathrm{A}_{2}$ (at anthesis) & $15.03 \mathrm{~b}$ & $30.24 \mathrm{a}$ & $34.34 \mathrm{a}$ & $36.94 \mathrm{a}$ & $7.207 \mathrm{a}$ & $14.03 \mathrm{a}$ & $16.93 \mathrm{a}$ & $19.05 \mathrm{a}$ \\
$\mathrm{A}_{3}$ (after anthesis) & $15.72 \mathrm{a}$ & $25.32 \mathrm{c}$ & $28.03 \mathrm{c}$ & $29.13 \mathrm{~b}$ & $7.395 \mathrm{a}$ & $12.94 \mathrm{~b}$ & $14.67 \mathrm{~b}$ & $15.67 \mathrm{~b}$ \\
\hline F-test & $* * *$ & $* * *$ & $* * *$ & $* * *$ & $* *$ & $* *$ & $* *$ & $* * *$ \\
\hline Mean & 14.649 & 28.263 & 32.670 & 33.966 & 6.74 & 13.169 & 16.963 & 17.512 \\
\hline
\end{tabular}

$* *, * *$ Significant at $0.01 \%$ and $0.001 \%$ level of probability, respectively.

Table 2. Mean effect of plant growth regulators $(\mathrm{H})$ and stages of application (A) on fruit weight (g) and fruit set in pathenocarpic fruit development in kakrol

\begin{tabular}{lcc}
\hline \multicolumn{1}{c}{ Treatment } & Fruit weight $(\mathrm{g})$ & Fruit set percent \\
\hline $\mathrm{H}_{1}(2,4-\mathrm{D})$ & $20.62 \mathrm{a}$ & $90.00 \mathrm{a}$ \\
$\mathrm{H}_{2}$ (Fulmet) & $9.307 \mathrm{~b}$ & $88.89 \mathrm{a}$ \\
$\mathrm{H}_{3}\left(\mathrm{GA}_{3}\right)$ & $1.493 \mathrm{c}$ & $75.56 \mathrm{~b}$ \\
$\mathrm{H}_{4}$ (NAA) & $1.574 \mathrm{c}$ & $68.89 \mathrm{c}$ \\
\hline F-test & $* * *$ & $* * *$ \\
\hline Mean & 8.248 & 80.835 \\
\hline $\mathrm{A}_{1}$ (Before anthesis) & $7.147 \mathrm{~b}$ & $93.33 \mathrm{a}$ \\
$\mathrm{A}_{2}$ (at anthesis) & $9.484 \mathrm{a}$ & $96.67 \mathrm{a}$ \\
$\mathrm{A}_{3}$ (after anthesis) & $5.30 \mathrm{c}$ & $80.00 \mathrm{~b}$ \\
\hline F-test & $* * *$ & $*$ \\
\hline Mean & 7.310 & 80.889 \\
\hline
\end{tabular}

*, *** Significant at 0.001 and $0.01 \%$ level of probability, respectively.

In this study, the performance of Fulmet was not much encouraging as compared to the other findings of different authors. For fruit length, the result showed that 2, 4-D produced longer fruits $(56.88 \mathrm{~mm})$ as compared to Fulmet, $\mathrm{GA}_{3}$ and NAA. The 2, 4-D 
enhanced the fruit growth sharply up to 10 DAS probably due to its higher capacity of cell division and cell enlargement thereby inducing parthenocarpy and then slowly up to 15 DAS. But with Fulmet the initial growth is low and slow increment onwards. In case of $\mathrm{GA}_{3}$ and NAA the initial growth is very low with a very little increase up to 15 DAS. Like fruit length, fruit diameter also increased gradually upto 10DAS with 2, 4-D and Fulmet, while it caused negligible increment with $\mathrm{GA}_{3}$ and NAA. Vajay and Jalicop (1980) observed higher fruit size by applying 2, 4-D and 2, 4, 5-T against NAA and IAA in kakrol. The highest fruit weight $(20.62 \mathrm{~g})$ was also obtained when the ovary was sprayed with 2, 4-D while the lowest fruit weight $(1.493 \mathrm{~g})$ was with $\mathrm{GA}_{3} \cdot \mathrm{GA}_{3}$ induced fruit weight, which was statistically similar with NAA. Krishnamoorty (1981) reported that the cytokinin influences the direction of transport of organic metabolites and minerals and their accumulation in the cell, which enhances fruit growth. Fulmet belonging to cytokinin group enhance transport of organic metabolites and consequently increase the growth of ovary in kakrol to some extent. Pathenocarpy fruit set of 'Khira' (a cucumber variety) was promoted by applying Fulmet externally (Kim et. al., 1992).

\section{Effect of spraying on stages of flower development}

The mean effect of stages of spraying viz. $A_{1}, A_{2}$ and $A_{3}$ for fruit length, fruit diameter, fruit weight and fruit set percent were statistically significant (Table 1and Table 2). The highest (96.67\%) fruit set was observed when the growth regulators were sprayed at anthesis followed by spraying one day before anthesis. It is believed that fruit set and development was caused by auxin due to rapid cell division and cell elongation of ovary. It was observed that some fruits developed without seeds indicating that the auxin content in the ovaries at the time of blooming was high enough for the ovary to commence growth even though there has been no fertilization (Gustafson, 1939). The treatment $A_{2}$ and $A_{1}$ was statistically similar for percent fruit set but different for $\mathrm{A}_{3}$. Regarding fruit weight, the highest fruit weight $(9.484 \mathrm{~g})$ was obtained from the treatment $\mathrm{A}_{2}$ which was closely followed by $A_{1}$. It seemed that the exogenous signal (phytohormones, auxin analogues) triggered an increase in endogenous IAA and its activity reached to its peak and sustained for long time in the ovary which was responsible for promoting the highest fruit set and development at the treatment. This interpretation is consistence with that of Gustafson (1939) and Kim et. al. (1992b). Our result indicated that growth regulators applied to the ovaries at anthesis induced parthenocarpic fruit in kakrol. In all treatments fruit length and fruit diameter increased sharply upto 10 days, then slowly and after that the fruit turned yellow and dropped (Fig 1).

\section{Interaction effect of spraying on stages of flower development $\times$ plant growth regulators on parthenocarpy}

Percent fruit set, fruit weight, fruit length and fruit diameter were significantly influenced by spraying on stages of flower development with different plant growth regulators (Table 3 and 4). The highest fruit set was obtained when 2, 4-D sprayed in the ovary one day before anthesis followed by the treatment combination of $\mathrm{A}_{2} \mathrm{H}_{1}$ (at anthesis). Percent fruit set was the lowest when the ovaries were treated with NAA one day after anthesis probably due to limitation of assimilate supply. The largest fruit was obtained from the treatment combination $\mathrm{A}_{2} \mathrm{H}_{1}(2,4-\mathrm{D}$ applied at anthesis) and the smallest from the treatment combination $\mathrm{A}_{1} \mathrm{H}_{3}\left(\mathrm{GA}_{3}\right.$ applied a day before anthesis). Fruit length and diameter 
were significantly increased by the treatment of 2, 4-D at anthesis and $A_{1}$ but reduced in $A_{3}$. The highest fruit length was obtained from the treatment combination $\mathrm{A}_{2} \mathrm{H}_{1}$ (2, 4-D application at anthesis) that was statistically similar to other treatment combinations.

Table 3. Interaction effect of plant growth regulators $(\mathrm{H})$ and stages of application (A) on fruit length $(\mathrm{mm})$ and fruit diameter $(\mathrm{mm})$ in inducing parthenocarpic fruit in kakrol

\begin{tabular}{|c|c|c|c|c|c|c|c|c|c|}
\hline \multirow{2}{*}{\multicolumn{2}{|c|}{ Treatment }} & \multicolumn{4}{|c|}{ Fruit length (mm) } & \multicolumn{4}{|c|}{ Fruit diameter $(\mathrm{mm})$} \\
\hline & & at spraying & 5 DAS & 10 DAS & 15 DAS & at spraying & 5 DAS & $10 \mathrm{DAS}$ & 15 DAS \\
\hline \multirow[t]{4}{*}{$\mathrm{A}_{1}$} & $\mathrm{H}_{1}$ & $12.45 \mathrm{~g}$ & $43.17 \mathrm{~b}$ & $62.56 \mathrm{a}$ & $63.45 \mathrm{a}$ & $6.103 \mathrm{ef}$ & $18.51 \mathrm{a}$ & $27.25 \mathrm{a}$ & $30.16 \mathrm{~b}$ \\
\hline & $\mathrm{H}_{2}$ & $13.07 \mathrm{fg}$ & $35.65 \mathrm{c}$ & $45.81 \mathrm{~b}$ & $48.58 \mathrm{~b}$ & $5 . .637 \mathrm{f}$ & $15.75 \mathrm{c}$ & $25.05 \mathrm{~b}$ & $26.50 \mathrm{c}$ \\
\hline & $\mathrm{H}_{3}$ & $14.28 \mathrm{cdef}$ & $19.34 \mathrm{~g}$ & $20.35 \mathrm{e}$ & $21.81 \mathrm{e}$ & $5.943 \mathrm{ef}$ & $7.893 \mathrm{e}$ & $8.680 \mathrm{f}$ & $9.213 \mathrm{f}$ \\
\hline & $\mathrm{H}_{4}$ & 13.77 efg & $17.66 \mathrm{i}$ & $18.90 \mathrm{~g}$ & $19.96 \mathrm{f}$ & $6.423 \mathrm{de}$ & $7.91 \mathrm{e}$ & $8.817 \mathrm{f}$ & $9.030 \mathrm{f}$ \\
\hline \multirow[t]{4}{*}{$\mathrm{A}_{2}$} & $\mathrm{H}_{1}$ & $16.77 \mathrm{ab}$ & $51.37 \mathrm{a}$ & $63.46 \mathrm{a}$ & $64.55 \mathrm{a}$ & $7.487 \mathrm{ab}$ & $18.63 \mathrm{a}$ & $28.69 \mathrm{a}$ & $37.20 \mathrm{a}$ \\
\hline & $\mathrm{H}_{2}$ & 15.04 cde & $34.83 \mathrm{~cd}$ & $39.52 \mathrm{c}$ & $42.87 \mathrm{c}$ & $7.153 \mathrm{bc}$ & $19.09 \mathrm{a}$ & $22.40 \mathrm{c}$ & $24.21 \mathrm{~d}$ \\
\hline & $\mathrm{H}_{3}$ & 13.92 defg & $17.27 \mathrm{i}$ & $18.03 \mathrm{~g}$ & $18.41 \mathrm{fg}$ & $6.860 \mathrm{~cd}$ & $8.927 \mathrm{~d}$ & $9.107 \mathrm{e}$ & $9.280 \mathrm{f}$ \\
\hline & $\mathrm{H}_{4}$ & $14.06 \mathrm{def}$ & $18.09 \mathrm{~h}$ & $18.57 \mathrm{~g}$ & $20.74 \mathrm{f}$ & $7.193 \mathrm{bc}$ & $8.88 \mathrm{~d}$ & $9.280 \mathrm{e}$ & $9.593 \mathrm{f}$ \\
\hline \multirow[t]{4}{*}{$\mathrm{A}_{3}$} & $\mathrm{H}_{1}$ & $15.12 \mathrm{cde}$ & $33.05 \mathrm{de}$ & $41.52 \mathrm{c}$ & $42.62 \mathrm{c}$ & $7.847 \mathrm{a}$ & $16.75 \mathrm{bc}$ & $23.58 \mathrm{bc}$ & $27.37 \mathrm{c}$ \\
\hline & $\mathrm{H}_{2}$ & 15.29 bcde & $26.48 \mathrm{ef}$ & $28.85 \mathrm{~d}$ & $30.30 \mathrm{~d}$ & $7.680 \mathrm{ab}$ & $16.06 \mathrm{c}$ & $16.77 \mathrm{~d}$ & $17.29 \mathrm{e}$ \\
\hline & $\mathrm{H}_{3}$ & $15.44 \mathrm{abc}$ & $16.95 \mathrm{i}$ & $17.54 \mathrm{gh}$ & $18.84 \mathrm{fg}$ & $7.327 \mathrm{ab}$ & $7.563 \mathrm{ef}$ & $7.907 \mathrm{f}$ & $8.177 \mathrm{f}$ \\
\hline & $\mathrm{H}_{4}$ & $16.90 \mathrm{a}$ & $17.78 \mathrm{i}$ & $18.40 \mathrm{~g}$ & $18.72 \mathrm{fg}$ & $6.413 \mathrm{dc}$ & $7.007 \mathrm{ef}$ & $7.323 \mathrm{f}$ & $7.607 \mathrm{f}$ \\
\hline F-test & & $* * *$ & $* * *$ & $* * *$ & $* * *$ & $* * *$ & $* * *$ & $* * *$ & $* * *$ \\
\hline Mean & & 14.675 & 27.636 & 32.792 & 34.237 & 6.838 & 12.747 & 16.237 & 17.969 \\
\hline $\mathrm{CV} \%$ & & 5.12 & 5.11 & 4.52 & 4.39 & 6.84 & 4.67 & 7.24 & 7.88 \\
\hline
\end{tabular}

*** Significant at $0.001 \%$ level of probability

Table 4. Interaction effect of plant growth regulators $(\mathrm{H})$ and stages of application (A) on fruit weight (g) and fruit set\% in inducing parthenocarpic fruit in karol

\begin{tabular}{cccc}
\hline \multicolumn{2}{c}{ Treatment } & Fruit weight $(\mathrm{g})$ & Fruit set percent \\
\hline $\mathrm{A}_{1}$ & $\mathrm{H}_{1}$ & $19.02 \mathrm{~b}$ & $96.67 \mathrm{a}$ \\
& $\mathrm{H}_{2}$ & $13.72 \mathrm{~d}$ & $93.33 \mathrm{a}$ \\
& $\mathrm{H}_{3}$ & $1.38 \mathrm{~g}$ & $93.33 \mathrm{a}$ \\
& $\mathrm{H}_{4}$ & $1.79 \mathrm{~g}$ & $88.33 \mathrm{ab}$ \\
$\mathrm{A}_{2}$ & $\mathrm{H}_{1}$ & $27.39 \mathrm{a}$ & $93.33 \mathrm{a}$ \\
& $\mathrm{H}_{2}$ & $10.45 \mathrm{e}$ & $90.00 \mathrm{ab}$ \\
& $\mathrm{H}_{3}$ & $1.48 \mathrm{~g}$ & $76.67 \mathrm{~cd}$ \\
& $\mathrm{H}_{4}$ & 1.393 & $75.00 \mathrm{cde}$ \\
$\mathrm{A}_{3}$ & $\mathrm{H}_{1}$ & $15.45 \mathrm{c}$ & $75.00 \mathrm{cde}$ \\
& $\mathrm{H}_{2}$ & $3.75 \mathrm{f}$ & $70.00 \mathrm{de}$ \\
& $\mathrm{H}_{3}$ & $1.620 \mathrm{~g}$ & $70.00 \mathrm{de}$ \\
& $\mathrm{H}_{4}$ & $1.54 \mathrm{~g}$ & $66.67 \mathrm{e}$ \\
\hline F-test & & $* * *$ & 82.36 \\
\hline Mean & \multicolumn{4}{c}{8.248} & 6.01 \\
\hline CV\% & 7.99 &
\end{tabular}

The highest fruit diameter was obtained from the treatment combination and $\mathrm{A}_{2} \mathrm{H}_{1}$ (2, 4-D applied at anthesis) closely followed by $\mathrm{A}_{1} \mathrm{H}_{1}$ which was statistically different from the other treatment combination and the lowest was obtained from $\mathrm{A}_{3} \mathrm{H}_{3}\left(\mathrm{GA}_{3}\right.$ applied a day after anthesis) which gave similar result with the treatment combination of $\mathrm{A}_{2} \mathrm{H}_{4}, \mathrm{~A}_{2} \mathrm{H}_{3}$ and $\mathrm{A}_{3} \mathrm{H}_{4}$. Watkins and Cantliffe (1980) reported that exogenously applied NAA enhanced fruit set depending on the position of application in Cucumis sativus L. which was not similar to 
our results which might be due to nature of the crop. Regarding fruit diameter, fruit length, fruit weight and fruit set 2, 4-D when applied a day before anthesis or at anthesis had better performance over other treatments.

In the present findings, among four growth regulators, 2,4-D showed better effect on growth and fruit set as compared to fulmet, $\mathrm{GA}_{3}$ and NAA probably due to its capacity to induce parthenocarpy in kakrol. The overall result revealed that 2,4-D applied at anthesis showed better performance over others in parthenocarpic fruit development of kakrol.

\section{REFERENCES}

Cantliffe, D. J. 1977. The induction of fruit set in cucumber by chloroflurenol with or without pollination. Hort. Sci. 7: 474-476.

Chin, R., Y. Hayata, Y. Niimi and R. Isoda. 1991. Effect of tomatotone or fulmet treatment on growth and quality of tomato fruit. J. Japan. Soc. Hort. Sci. 60(suppl.1): 276-277 (in Japanese).

Choudhury, B and S. C. Phatak. 1958. Sex expression and fruit development in cucumber (Cucumis sativus L) as affected by gibberellin. Indian J. Hortic.16: 233-235.

Das, B. C. 1988. "Kakrol Cash” $1^{\text {st }}$ ed. Sima Devi. Malakutir, Baganbari, Brahmanbaria, p. 45.

Elassar, G., J. Rudich and N. Kedar. 1974b. Parthenocarpic fruit development Muskmelon induced by Growth Regulators. Hort. Sci. 9(6): 577.

Elassar, G., J. Rudich, D. Palevitch and N. Kedar. 1974a. Induction of parthenocarpic fruit development in cucumber by growth regulators. Hort. Sci. 9(3): 238-239.

Gotou, T., K. Kamada, U. Yoshida and M. Yukinaga. 1989. Growth and ripening of parthenocarpic melon fruit induced by authentic cytokinin, 4 PU-30. J. Japan. Soc. Hort. Sci. 58(1): 326-327 (in japanese).

Gustafson, F. G. 1939. The cause of natural parthenocarpy Amer. J. Bot. 26: 135-138.

Hayata, Y., Y. Niimi and N. Twasaki. 1995. Synthetic Cytokinin -1-(2-chloro-4 pyridyl)-3 phenylurea (CPPU). promotes fruit set and induces parthenocapy in watermelon. J. Amer. Soc. Hort. Sci. 120: 997-1000.

Kim, I. S., H. Okubo and K. Fujieda. 1992. Endogenous levels of IAA in relation to parthenocarpy in cucumber (Cucumis sativus L.). Scientia Horticulturae, 52: 1-8.

Krishnamoorty, N. H. 1981. Plant Growth Substances. Tata McGraw-Hill Publishing Company Limited, New Delhi, pp. 88-105.

Lee, T. H., A. Sugiyama, K. Takeno, H. Ohno and S. Yamaki. 1997. Changes in the content of indole-3- acetic acid and its activity of sucrose metabolizing enzyme during fruit growth in eggplant (Solanum melongena L.). J. Pl. Physiol. 150: 292-296.

Lewis, O. H., G. K. Burge, M. E. Hopping and P. E. Jameson.1996. Cytokinin and fruit development in the Kiwifruit (Actinidia deliciosa): Effect of reduced pollination and CPPU application. Pl. Physiol. 98:187-195.

Manik, N. I. 1998. Parthenocarpic fruiting behaviour in kakrol (Momordica dioica Roxb.). An M. S. Thesis submitted to the Department of Horticulture, BSMRAU, Salna, Gazipur, pp: 1-62.

Ohara, H., J. Izawa, S. Kimura, N. Hiroi, H. Matsui, N. Hirata and E. Takahashi. 1997. Induction of fruit set and growth of parthenocarpic 'Hayward' kiwifruit with plant growth regulators. J. Japan. Soc. Hort. Sci. 66: 473-667 (in japanese with English summary).

Rashid, M. M. 1993. Sabjee Biggan. Bangla Academy. Dhaka. Bangladesh.

Rasul, M. G. 2003. Study of parthenocarpy and genetic divergence in kakrol. Ph.D. Thesis.submitted to Kyushu University, Fukuoka, Japan. pp: 49-76.

Schwabe, W. W. and J. J. Mills. 1981. Hormones and parthenocarpic fruit set: A literature survey. Hortic. Abstr. 51: 661-698.

Shishido, Y., Y. Hori and S. Shikano. 1990. Effect of benzyladenine on translocation and distribution of photoassimilates during fruit setting and development in cucumber plant. J. Japan Soc. Hort. Sci. 59: $129-135$.

Vijay, O. P. and S. H. Jalikop. 1980. Production of parthenocarpic fruit by growth regulatons in kakrol (Momordica cochinchinensis Spreng). India J. Hort. 37(2): 167-169.

$\mathrm{Yu}$, J. Q. 1999. Parthenocarpy induced by CPPU [N- (2-choloro-4-pyridyl)-3- phenylurea] prevents fiower abortion in Chinese white-fiowered gourd (Lagenaria leucantha). Environ. Exp. Bot. 42: 121-128. 